\title{
Promoting Leadership Effectiveness in Organizations: A Case Study on the Involved Factors of Servant Leadership
}

\author{
Hamideh Shekari (Corresponding author) \\ Management Department, Payame Noor University \\ Taft, Yazd, I. R. of Iran \\ Tel: +98-913-356-5884 E-mail: L_shekari60@yahoo.com \\ Mahmood Zare Nikooparvar \\ Accounting Department, Payame Noor University \\ Taft, Yazd, I. R. of Iran
}

Received: November 2, 2011

Accepted: December 9, 2011 Published: January 5, 2012

doi:10.5430/ijba.v3n1p54

URL: http://dx.doi.org/10.5430/ijba.v3n1p54

\begin{abstract}
The world is crying out for ethical and effective leadership that serves others, invests in their development and fulfills a shared vision. Among the many leadership styles (i.e., authoritarian, benevolent dictatorship, participatory, etc.) the one that best represents the ideals embodied in the human factor is servant-leadership. Servant-leadership incorporates the ideals of empowerment, total quality, team building, and participatory management, and the service ethic into a leadership philosophy. This model of leadership emphasizes increased service to others; a holistic approach to work; promoting a sense of community; and the sharing of power in decision making. Servant-leaders must be value- and character-driven people who are performance and process oriented. The aim of this paper is determining the drivers of servant leadership in order to put servanthood behaviors activities into practice among leaders. So at first we developed literature on servant leadership. Then Thirty-three measurement items were developed on the basis of opinions from leaders and the literature. Then Data collection occurred via a questionnaire. To validate the measurement scales for servant leadership, we performed a factor analysis. The results show that a six-factor measurement model (including emotional dimension, commitment to community, egalitarianism, altruism, managerial skills and human skills) fits the data acceptably. All of the measurement items significantly loaded on the constructs on which they were hypothesized to load. These results gave us confidence that the measures are indeed valid and reliable.
\end{abstract}

Keywords: Servant Leaders, Servant Leadership Dimensions, Factor Analysis

\section{Introduction}

In today's thinking about effective, productive, and enduring organizations, we can reorganize, restructure, or reengineer our organization to be more effective but it will not be successful for very long, unless change is first built on the preeminence of human resources. People and process will always be more important than tasks and organizational structure in accomplishing goals and productivity. Effective systems and processes are only effective if the people who make them work are effective. Highly motivated and well-trained human resources provide the only assurance that any organization will be effective in accomplishing its goals. Leaders motivate followers through investing in them and empowering them to do their best.

Leadership involves the use of character to overcome an external challenge. Effective leadership simplifies the complex, sets aside doubt and makes action compelling and successful. Leaders have the capacity to convert purpose and vision into action. Most leaders are pragmatic dreamers or practical idealists. The traditional model of leadership is that of the charismatic leader. Power is the magnet, which attracts such leaders, and most, are corrupted and destroyed by power (Davies, 2002). Therefore, The words servant and leader are usually thought of as being opposites. In deliberately bringing those words together in a meaningful way, Robert Greenleaf gave birth to the paradoxical term servant-leadership (SL) (Spears, 1998). The concept of servant-leadership appears to be so complex as to defy simple definition - it is multi-dimensional, rich in hues and wide-ranging in its meanings. The servant-leadership literature has freely borrowed terms from different disciplines. Religious terms such as God, soul, and spirit and psychological 
concepts such as personal growth, self-awareness, and identify are mixed with management "buzz words" such as flat organization and shared vision.

It is the fundamental attitude of servanthood that influences how leaders work with followers and how they carry out the task of leadership. Too often, leaders have been task- or process-oriented without the heart for serving others. Table 1 appreciates what servant leadership entails that is so different from command-and-control types of leadership. Table 1 Summarizes comparison of some of the extreme differences in attitudes and attributes in these two leadership paradigms.

$<$ Table 1 about here $>$

Servant-leadership cannot prevail, however, unless there is a fundamental change in organizational attitudes and behavior. In this new organizational structure, the leader becomes the soft glue that holds the organization together as a virtual community working together. This glue is made up of a sense of common identity, linked to a common purpose and fed by an infectious energy and urgency. That is the task for a leader who is taking his or her institution into the twenty-first century. Critical to their success will be the creation of healthy and productive relations between the CEO and the employees, between the pastor and the congregation, between the president, the faculty, and students (Handy, 1996).

\section{Literature Review}

\subsection{Servant Leadership and Servant Leader}

For an organization to be effective, it is imperative that the unique talents of its employees be recognized, utilized, and developed. Leaders can play a critical role in helping employees to realize their potential (Liden et. al., 2000). An approach to leadership called servant leadership focuses on developing employees to their fullest potential in the areas of task effectiveness, community stewardship, self-motivation, and future leadership capabilities (Liden et.al., 2008).

Servant leadership is an emerging model of leadership characterized by its emphasis on strong follower-centric, altruistic, moral/ethical, and spiritual values (Smith et al., 2004). In contrast to leaders who see people merely as units of production or expendable resources in a profit and loss statement, servant leaders empower followers to grow healthier, wiser, freer, more autonomous, and more likely themselves to become servants. Moreover, unlike transformational leadership whose primary concern is performance beyond expectations the sine qua non of servant leadership is followers' holistic development. So, servant leaders employ relational power that facilitates post-conventional moral reasoning and spiritual considerations in others (Pekerti and Sendjaya, 2010).

Patterson defines servant leaders as those leaders who lead an organization by focusing on their followers, such that the followers are the primary concern and the organizational concerns are peripheral and followers as those who are subordinate to a given leader within a given organization and suggests the terms subordinates and employees can be used interchangeably (Patterson, 2003).

Servant leaders are first and foremost servants who fulfil a desire to serve others. The expression of servant leadership characteristics in service to others is putting other people first. Every leader should have a 'servant's heart', show care and concern for others and be mentor minded, that is, have the desire and concern to build and develop others, even at his or her own expense (Waterman, 2011).

Servant leaders place the needs of their subordinates before their own needs and center their efforts on helping subordinates grow to reach their maximum potential and achieve optimal organizational and career success (Greenleaf, 1977).

Servant leaders motivation in accomplishing their tasks is not self-interest; rather, servant leaders want their subordinates to improve for their own good, and view the development of followers as an end, in and of itself, not merely a means to reach the leader's or organization's goals. In this sense, servanthood extends beyond the desires of the self-ego and builds a working climate that generates feelings of employee empowerment. Also servant leadership extends beyond the workplace to foster within followers a spirit of servanthood, or working to create value for the community at large (Liden et.al., 2008).

Servant leaders build trust by selflessly serving others first. The theme of serving others before oneself extends from the workplace to home and community. In all aspects of life, servant leaders practice this service orientation. They instill in followers the self-confidence and desire to become servant leaders themselves. Through this transformation of followers into servant leaders, a culture of servant leadership can be created (Greenleaf, 1977). 
Servant leaders function as stewards who regard their followers as people who have been entrusted to them to be elevated to their better selves and to be what they are capable of becoming. Followers tend to respond well to servant leaders because they have proven themselves trustworthy as servants (Pekerti and Sendjaya, 2010).

Servant leadership differs from other models of leadership in that it focuses on leaders meeting the needs of followers, in that, if followers are treated as ends in themselves, rather than means to an end, they will reach their potential and so perform optimally. Such an approach is found when leaders respect, value and motivate those who follow them (McCrimmon, 2010).

\subsection{Servant Leadership Dimensions}

The servant leadership literature offers an inconsistent set of dimensions that define this construct (Barbuto and Wheeler, 2006), Liden et.al. (2008) identified nine dimensions:

1. Emotional healing - the act of showing sensitivity to others' personal concerns

2. Creating value for the community - a conscious, genuine concern for helping the community

3. Conceptual skills - possessing the knowledge of the organization and tasks at hand so as to be in a position to effectively support and assist others, especially immediate followers

4. Empowering - encouraging and facilitating others, especially immediate followers, in identifying and solving problems, as well as determining when and how to complete work tasks

5. Helping subordinates grow and succeed—-demonstrating genuine concern for others' career growth and development by providing support and mentoring

6. Putting subordinates first - using actions and words to make it clear to others (especially immediate followers) that satisfying their work needs is a priority (Supervisors who practice this principle will often break from their own work to assist subordinates with problems they are facing with their assigned duties.)

7. Behaving ethically—interacting openly, fairly, and honestly with others

8. Relationships - the act of making a genuine effort to know, understand, and support others in the organization, with an emphasis on building long-term relationships with immediate followers

9. Servanthood - a way of being marked by one's self-categorization and desire to be characterized by others as someone who serves others first, even when self-sacrifice is required

Ehrhart believes that servant leadership is composed of seven dimensions (Ehrhart, 2004):

1. Forming relationships with subordinates

2. Empowering subordinates

3. Helping subordinates grow and succeed

4. Behaving ethically

5. Having conceptual skills

6. Putting subordinates first

7. Creating value for those outside the organization

Pekerti and Sendjaya identified six dimensions of servant leadership. These dimensions are listed below (Pekerti and Sendjaya, 2010):

1. The voluntary subordination dimension bears some content resemblance to the humane leadership dimension. The humane leadership dimension signifies a generous, compassionate, and modest leader (Dorfman et al., 2004) whereas the voluntary subordination dimension represents a self-sacrificial, follower-centric, altruistic leader.

2. The authentic self dimension refers to the notion of leadership that flows out of being or a strong sense of who we are (as opposed to what we do). Knowing and being true to one's self, servant leaders are able to lead authentically (Autry, 2001) with their humility, integrity, accountability, vulnerability, and a secure sense of self consistently displayed through their decisions and actions. People with an individualistic and/or independent self-construal are more likely to be authentic across situations.

3. Power distance is another dimension that relates to authentic self. Subordinates in high power distance societies are less willing to question, challenge, and express disagreement with their supervisors than their counterparts in low power distance societies. The covenantal relationship dimension has a degree of overlap with team orientated dimensions. In 
contrast with contractual relationships, servant leaders build covenant with their constituents based on shared values and understanding, open-ended commitment, mutual trust, and concern for the welfare of the other party. They accept people as they are, collaborate with others to tap into their individual varied talents, and make themselves available to nurture that profound, lasting relationship. These relationship-focused and followers-oriented descriptions also fit those of the team-oriented leadership dimension.

4. The responsible morality dimension represents the reflective moral reasoning that servant leaders employ to ensure that both the process and outcomes of their leadership are thoughtfully reasoned and ethically justifiable. This emphasis on the moral aspects will foster a positive organizational ethical climate.

5. The transcendental spirituality dimension represents behaviours that reflect a sense of self-awareness, interconnectedness, mission and wholeness, which enable others to lead a holistic, integrated, and productive life through service.

6. The transforming influence dimension exemplifies the articulation and implementation of a shared vision which gives inspiration and meaning to one's work so much so that the people served experience positive transformation in multiple dimensions (e.g., emotionally, intellectually, socially and spiritually) into servant leaders themselves. This dimension parallels that of charismatic leadership, which takes into consideration the followers' values and aspiration in the development of the leadership vision.

\subsection{Characteristics of Servant Leaders}

Larry C. Spears orders 10 characteristics for servant leaders as follows (Spears, 1996; Waterman, 2011):

1. Self Awareness

2. Listening

3. Foresight

4. Empathy

5. Conceptualisation

6. Healing

Relationships

7. Persuasion

8 .Commitment to growth of others

9. Building community

Tasks/Resources

\section{Stewardship}

These ten characteristics of servant-leadership are by no means exhaustive. However, they do serve to communicate the power and promise that this concept offers to those who are open to its invitation and challenge.

Warren Bennis identified 10 traits of 'servant leaders which are listed below (Davies, 2002):

1. Bias towards action

2. Leadership of women

3. Self-awareness and self-esteem

4. Generate trust

5. Great vision with meaning

6. Purpose and vision

7. Act big if small — act small if big

8. Make federations of corporations

9. Comfortable with technology

10. Porous and permeable boundaries 


\subsection{Advantages and Disadvantages of Servant Leadership}

The benefits of servant leadership are impressive and widespread. Some of the Advantages of servant leadership that account for its pervasiveness in organizations are listed below (Waterman, 2011):

- Values people and treat them as ends rather than means.

- Enables others to develop and flourish.

- Shows commitment to the community.

- Expresses a human face in an often impersonal environment.

- Puts back the concept of caring into care.

- Seeks to improve care through encouragement and facilitation, rather than through power and authority.

- Improves performance by developing and nurturing followers

Waterman (2011) states some disadvantages for servant leadership:

- Is similar to transformational leadership approaches.

- Fails into a target-fixated system.

- Disturbs the concept of hierarchy.

- Can be perceived as a religious concept and therefore alien to modern sensitivities.

- The title of servant can be seen as detrimental to nurses.

- Humility can be perceived as weakness.

- Some workers may not respond to this approach.

\subsection{An Example: Servant Leadership at Southwest Airlines}

This is an example of how the very theoretical leadership approach of Servant Leadership can be implemented in the corporate culture of a company. Southwest Airlines is one of the largest airlines in the U.S. and often mentioned in relation to servant leadership.

Co-founder and former CEO Herb Kelleher and former vice president Colleen Barrett have successfully established the management style of servant leadership in the airline's corporate culture. The pyramid of the company's priorities is build upside down compared to other companies. The employees are at the top of the pyramid and the executives deliver proactive customer service to them. If they do a good job, the employees can spend their time to service the second important group, the customers. As result of good service to the customers the company will make good profit which is of interest of the shareholders. Herb Kelleher compares leadership with customer service: "Just as Southwest has their customers, the passengers, the management has their customers, the employees. If the customers are not satisfied, they will not fly again with Southwest. If the employees are not satisfied, they will not deliver the required performance."

Leadership expectations at Southwest: develop people, build great teams, think strategically, excellent results and the identification with the values of the company. Based on these expectations it becomes clear how the theoretical approach to specific guidelines and principles of conduct was formulated. Therefore it is paid very careful attention if potential employees meet the values of the company: "Hire for attitude and train for skill". The value system consists of three core values: "warrior spirit", as defined by the desire to get excellent results, "a servant's heart" or "to put others first", as well as "a fun-loving attitude," which means not to take themselves too seriously. The executive's purpose is also to create a very positive and familiar working environment. The "fun" image of Southwest has become an important part of the corporate culture. It's also in the company's best interests to communicate this to their customers. These are also characteristics of the behavior of a servant leader: active listening, empathy, healing and the formation of a community.

Another important executive function at Southwest Airlines is the development of people. The employees are motivated to participate in decision-making. They should be encouraged to solve problems themselves and to grow by personal success. The obligation to develop the individual also corresponds to the concept of Servant Leadership.

Further expectations of the managers are strategic thinking and outstanding results. The following guidelines serve to guide: strive for continuous improvement, understanding of the context of current actions and implications for the future, strategic goals into specific action plans and future-oriented view of things. The courage to conceptualize and far-sighted visions are also within the meaning of the servant leadership approach. Through the personal identification with the goals of the company, performance and commitment increases. 


\section{Research Methodology}

The aim of this paper is determining the drivers of servant leadership in order to put servanthood behaviors into practice in Iranalloysteel. This type of industry is significant within Iran. Experiences from this industry may be useful for other Iranian industries.

At first the literature on servant leadership was gathered. At the next step thirty-three measurement items were developed on the basis of opinions from experts and the literature. The data used in this study consist of questionnaire responses from leaders in Iranalloysteel. The questionnaire included items of servant leadership. A total of 340 responses were received. To validate the measurement scales for servant leadership, we performed a factor analysis.

\section{Determining the Measurement Items}

Thirty-three measurement items were developed on the basis of opinions from experts and the literature. The measurement items are as follows:

1. Listening carefully to others (Covey, 2002; Drury, 2004; Ekundayo et al., 2010; Waterman, 2011)

2. Empathy (Spears, 1996; Thompson, 2002; Ekundayo et al., 2010; Waterman, 2011)

3. Recognize low morale (Pekerti and Sendjaya, 2010; Reed et al., 2011)

4. Foresight (Spears, 1996; Horsman, 2001; Covey, 2002; Ramer, 2008; Waterman, 2011)

5. Awareness (Davies, 2002; Ramer, 2008; Waterman, 2011; Pekerti and Sendjaya, 2010)

6. Persuasion (Spears, 1996; Drury, 2004; Crippen, 2005; Ekundayo et al., 2010; Waterman, 2011)

7. Stewardship (Ledbetter, 2003; Nelson, 2003; Ekundayo et al., 2010; Waterman, 2011)

8. Sacrifice personal benefits (Reed et al., 2011)

9. Behave subordinates ethically (Ehrhart, 2004; Smith et al., 2004; Liden et.al., 2008; Johnson, 2009)

10. Behave subordinates fairly (Smith et al., 2004; Liden et.al., 2008; Johnson, 2009)

11. Emotional healing (Liden et.al., 2008; Spears, 1996; Waterman, 2011)

12. Helping subordinates succeed (Rowe, 2003; Whetstone, 2002; Ehrhart, 2004; Liden et.al., 2008)

13. Concern for helping the community (Liden et.al., 2008)

14. Creating trust (Russell and Stone, 2002; Davies, 2002; Errol \& Winston, 2005; Pekerti and Sendjaya, 2010)

15. Valuing people (Waterman, 2011; Freeman, 2011)

16. Encourage debate (Reed et al., 2011)

17. Valuing diversity and difference (Reed et al., 2011)

18. Treat people as ends rather than means (McCrimmon, 2010; Freeman, 2011; Waterman, 2011)

19. Sensitivity to employees' personal obligations outside the workplace (Reed et al., 2011)

20. Forming fair relationships with subordinates (Liden et.al., 2008; Pekerti and Sendjaya, 2010)

21. Encourage constructive criticism (Reed et al., 2011)

22. Make federations of corporations (Russell, 2001; Davies, 2002; Ledbetter, 2003)

23. Concern for effects of decisions on community (Reed et al., 2011)

24. Creating value for those outside the organization (Ehrhart, 2004; Liden et.al., 2008;)

25. Bias towards action (Davies, 2002)

26. Comfortable with technology (Davies, 2002)

27. Commitment to growth of others (Spears, 1996; Waterman, 2011)

28. Putting subordinates first (Patterson, 2003; Ehrhart, 2004; Liden et.al., 2008; Gillet et al., 2010)

29. Purpose and vision (Davies, 2002; Russell and Stone, 2002; Banutu-Gomez, 2004; Freeman, 2011)

30. Engages in community service and volunteer activities outside of work (Reed et al., 2011)

31. Empowering subordinates (Russell and Stone, 2002; Stone et al., 2004; Ehrhart, 2004; Liden et.al., 2008; Freeman, 2011) 
32. Serve with no expectation of reward (Wong and Page, 2003; Liden et.al., 2008; Jaramillo et al., 2009)

33. Conceptual skills (Spears, 1996; Starratt, 2004; Ehrhart, 2004; Liden et.al., 2008; Waterman, 2011)

\section{Factor Analysis and Discussion}

An exploratory factor analysis was conducted to derive groupings of servant leadership from the survey data. Since the Kaiser criterion was 0.889 and Bartlett's measure was 89.11, we can conduct the factor analysis. The results of exploratory factor analysis are shown in Table 2.

$<$ Table 2 about here $>$

This factor analysis empirically grouped the scale items of servant leadership into six factors. The results show that a six-factor measurement model (including altruism, egalitarianism, emotional dimension, managerial skills, human skills and commitment to community) fits the data acceptably, see Figure 1.

$<$ Figure 1 about here $>$

The six factors can be labeled as follows:

The first factor can be labeled as altruism and consists of measurement items 8, 12, 27, 28, 31 and 32. Altruism is at the core of Greenleaf's notion of servant leadership and has been shown by other leadership scholars to exert a positive impact on employee motivation and performance (Avolio et al., 2009).

The second factor can be labeled as egalitarianism and consists of measurement items 9, 10, 16, 17, 20 and 21. An important feature of servant leadership is egalitarianism, rejecting the notion that leaders are inherently superior to other organizational members and understanding that learning and influence are multi-directional processes. Greenleaf considered an egalitarian perspective central to servant leadership within the firm (Reed et al., 2011).

The third factor is labeled as emotional dimension and consists of measurement items 1, 2, 3, 11 and 19. Servant leaders employ relational and emotional power to motivate people (Pekerti and Sendjaya, 2010).

The forth factor is labeled as managerial skills and consists of measurement items 4, 7, 25, 26, 29 and 33. In addition to relational and emotional dimension for motivating people, servant leaders need managerial skills to manage the organization efficiently. They need bias towards action, they need great vision with meaning, they have to determine Purposes and goals, they have to be comfortable with new technologies (Davies, 2002).

The fifth factor is labeled as human skills and consists of measurement items 5, 6, 14, 15 and 18. In contrast to leaders who see people merely as units of production or expendable resources in a profit and loss statement, servant leaders Treat people as ends rather than means (McCrimmon, 2010; Waterman, 2011). They use their human skills to motivate people.

The last factor is labeled as commitment to community and consists of measurement items 13, 22, 23, 24 and 30 . The servant-leader senses that much has been lost in recent human history as a result of the shift from local communities to large institutions as the primary shaper of human lives. This awareness causes the servant-leader to seek to identify some means for building community among those who work within a given institution. Servant-leadership suggests that true community can be created among those who work in businesses and other institutions (Spears, 1996). Greenleaf said, "All that is needed to rebuild community as a viable life form for large numbers of people is for enough servantleaders to show the way, not by mass movements, but by each servant-leader demonstrating his or her unlimited liability for a quite specific community-related group." (Greenleaf, 1977).

The goodness-of-fit statistics (CFI $=0.90 ; \mathrm{GFI}=0.82 ; \mathrm{NFI}=0.87$; TLI $=0.89 ; \mathrm{RMR}=0.076)$ suggest that the data fit the measurement model reasonably well. In addition, we examined the patterns of the standardized residuals and these residuals have no impact on the model fitness.

Further analysis confirms the reliability of these six factors with Cronbach's alpha, of $0.79,0.78,0.92,0.83,0.76$ and 0.71 respectively, for each group. All Cronbach's alpha values are well above the limit of 0.70 and ensure the constructs' internal consistency and validity.

\section{Conclusion}

As many organizations turn to servant leadership, it will be increasingly important to clarify exactly what it is and how it works. Servant leadership is more than a leadership style that fits normative advice and religious norms for leadership. Servant leadership not only fits the prescriptions of religion, It works (Ebener and O'Connell, 2010).

The servant leader is more inclined to serve than to be served, recognize rather than to be recognized, and empower rather than to flex positional power by commanding and controlling the response of followers. If leaders place 
themselves in humble service to their organization, recognize the gifts and talents of others, and call them forth through empowering actions, then the people will respond with organizational citizenship behaviors by helping each other, taking initiative, participating in various activities, and taking responsibility to continuously develop themselves as potential leaders of their organizations. Servant Leadership is a way of life that deeply enhances our culture and our business. It's what makes us such a great place to work. However, servant leadership is still a new concept in Iran. Some Iranian enterprises have recognized its importance and tried to put it into practice, but most of these enterprises may lack experience as well as necessary management skills. In summary for improving the effectiveness of leadership, Iranian enterprises should develop servanthood behaviors mentioned in the model, specially, behaviors such as Helping subordinates succeed, Putting subordinates first, Forming fair relationships with subordinates, Listening carefully to others, Foresight, Awareness, Concern for helping the community, etc.

However, here are some other important points for effective servant leadership (Greenleaf, 1977):

- Leaders do not say, "Get going." Instead, they say, "Let's go!" and lead the way. They do not walk behind with a whip; they are out in front with a banner.

- Leaders assume that their followers are working with them. They consider others to be their partners in the work and see to it that they share in the rewards, and they glorify the team spirit.

- Leaders are people builders. They help people to grow because the leader realizes that the more people grow, the stronger the organization will be.

- $\quad$ Leaders do not hold people down - they lift them up. They reach out their hand to help their followers scale the peaks.

- Leaders have faith in people. They believe in them. They have found that others will rise to high expectations.

- Leaders use their heart as well as their head. After they have looked at the facts with their head, they let their heart take a look too.

- Leaders keep their eyes on high goals. They are self-starters. They create plans and set them in motion. They are people of thought and action - both dreamers and doers.

- Leaders are faced with many hard decisions, including balancing fairness to an individual with fairness to the group. This sometimes requires "weeding out" those in the group who, over a period of time, do not measure up to the group needs of dependability, productivity and safety.

- Leaders have a sense of humor. They are not stuffed shirts. They can laugh at themselves. They have a humble spirit.

- Leaders can be led. They are not interested in having their own way, but in finding the best way. They have an open mind.

\section{References}

Autry, J. A. (2001). The Servant Leader. Roseville, CA: Prima.

Avolio, B. J., Walumbwa, F. O. \& Weber, T. J. (2009). Leadership: Current Theories, Research, and Future Directions. The Annual Review of Psychology 60, 421-449. http://dx.doi.org/10.1146/annurev.psych.60.110707.163621

Barbuto, J., \& Wheeler, D. (2006). Scale development and construct clarification of servant leadership. Group \& Organization Management, 31, 300-326. http://dx.doi.org/10.1177/1059601106287091

Banutu-Gomez, M. B. (2004). Great leaders teach exemplary followership and serve as servant leaders. The Journal of the American Academy of Business, 4(1), 143-152.

Covey, S. R. (2002). Servant-leadership and community leadership in the twenty-first century. In L. C. Spears \& M. Lawrence (Eds.), Focus on leadership: Servant leadership for the 21st century (27-33). New York: John Wiley \& Sons.

Crippen, C. (2005). The Democratic School: First to serve, then to lead. Canadian Journal of Educational Administration and Policy, Issue 47.

Davies, A. (2002). Focus on Leadership —-Servant-Leadership for the 21st Century. Edited by Larry Spears and Michele Lawrence, Wiley.

Dorfman, P. W., Hanges, P. J. \& Brodbeck, F. C. (2004). Leadership and Cultural Variation, in Culture Leadership and Organizations: The GLOBE Study of 62 Societies. Eds. R.J. House, P.J. Hanges, M. Javidan, P.W. Dorfman and V. Gupta, London: Sage, pp. 669-722. 
Drury, S. (2004). Employee Perceptions of Servant Leadership: Comparisons by Level and with Job satisfaction and Organizational Commitment. Doctoral Dissertation, Regent University, School of Leadership Studies, USA.

Greenleaf, R. K. (1977). Servant leadership: A journey into the nature of legitimate power and greatness. New York: Paulist Press.

Ebener, D. R. \& O’Connell, D. J. (2010). How Might Servant Leadership Work?, Nonprofit Management \& Leadership, vol. 20, no. 3, 315-335. http://dx.doi.org/10.1002/nml.256

Ehrhart, M. G. (2004). Leadership and Procedural Justice Climate as Antecedents of Unit-Level Organizational Citizenship Behavior. Personnel Psychology, 57 (March), 61-94. http://dx.doi.org/10.1111/j.17446570.2004.tb02484.x

Ekundayo, M. O., Damhoeri, K. \& Ekundayo, S. M. (2010). Presenting the Servant Leadership Model as a Panacea to Bad Leadership in Tertiary Education in West Africa. Academic leadership, Volume 8, Issue 4.

Errol, E. J., \& Winston, B. E. (2005). A correlation of servant leadership, leader trust, and organizational trust. Leadership \& Organization Development Journal, 26(1), 6-22. http://dx.doi.org/10.1108/01437730510575552

Freeman, G. T. (2011). Spirituality and Servant Leadership: A Conceptual Model and Research Proposal. Emerging Leadership Journeys, Vol. 4, Iss. 1, pp. 120- 140.

Gillet, J., Cartwright, E., \& Van Vugt, M. (2010). Selfish or servant leadership? Evolutionary predictions on leadership personalities in coordination games. Personality and Individual Differences. http://dx.doi.org/10.1016/j.paid.2010.06.003

Handy, C. (1996). The New Language of Organizing and Its Implications for Leaders. F. Hesselbein, M. Goldsmith and R. Beckhard, eds. The Leader of the Future: New Strategies, and Practices for the Next Era. San Francisco, CA: Jossey-Bass.

Horsman, J. H. (2001). Perspectives of servant-leadership and spirit in organizations. Unpublished dissertation, Gonzanga University, Spokane, WA.

Jaramillo, F., Grisaffe, D. B., Chonko, L. B. \& Roberts, J. A. (2009). Examining the impact of servant leadership on salespersons turnover intention. Journal of Personal Selling \& Sales Management, vol. XXIX, no. 4, 351-365. http://dx.doi.org/10.2753/PSS0885-3134290404

Johnson, C. E. (2009). Meeting the Ethical Challenges of Leadership: Casting Light or Shadow. 3rd Edition, Sage, Thousand Oaks.

Ledbetter, D. S. (2003). Law enforcement leaders and servant leadership: A reliability study of the organizational leadership assessment. Unpublished Dissertation, Regent University, City, ST.

Liden, R. C., Wayne, S. J., \& Sparrowe, R. T. (2000). An examination of the mediating role of psychological empowerment on the relations between job, interpersonal relationships, and work outcomes. Journal of Applied Psychology, 85, 407-416 http://dx.doi.org/10.1037/0021-9010.85.3.407

Liden, R. C., Wayne, S. J., Zhao, H. \& Henderson, D. (2008). Servant leadership: Development of a multidimensional measure and multi-level assessment. The Leadership Quarterly 19, 161-177. http://dx.doi.org/10.1016/j.leaqua.2008.01.006

McCrimmon, M. (2010). Servant Leadership, www.leadersdirect.com/servant-leadership (last accessed: December 20 2010).

Nelson, L. (2003). An exploratory study of the application and acceptance of servant-leadership theory among black leaders in South Africa. Doctoral dissertation, Regent University, Virginia Beach, VA. (UMI AAT 3086676).

Patterson, K. A. (2003). Servant leadership: A theoretical model. Doctoral dissertation, Regent University (UMI No. 3082719).

Pekerti, A. A. \& Sendjaya, S. (2010). Exploring servant leadership across cultures: comparative study in Australia and Indonesia. The International Journal of Human Resource Management, Vol. 21, No. 5, 754-780. http://dx.doi.org/10.1080/09585191003658920

Ramer, L. M. (2008). Using Servant Leadership to Facilitate Healing After a Drug Diversion Experience. Volume 88, Issue 2, 253-258. http://dx.doi.org/10.1016/j.aorn.2008.05.002

Reed, L. L., Vidaver-Cohen, D. \& Colwell, S. R. (2011). A New Scale to Measure Executive Servant Leadership: Development, Analysis and Implications for Research. Journal of Business Ethics 101, 415-434. http://dx.doi.org/10.1007/s10551-010-0729-1

Rowe, R. (2003). Leaders as servants. New Zealand Management, 50(1), 24-26.

Russell, R. F. (2001). The role of values in servant leadership. Leadership \& Organization Development Journal, 22, 7683. http://dx.doi.org/10.1108/01437730110382631

Russell, R. F. \& Stone, A. G. (2002). A review of servant leadership attributes: Developing a practical model. Leadership \& Organization Development Journal, 23(3), 145-157. http://dx.doi.org/10.1108/01437730210424 
Smith, B. N., Montagno, R. V. \& Kuzmenko, T. N. (2004). Transformational and Servant Leadership: Content and Contextual Comparisons. Journal of Leadership and Organizational Studies, 10, 80-92. http://dx.doi.org/10.1177/107179190401000406

Spears, L. C. (1996). Reflections on Robert K Greenleaf and servant leadership. Leadership and Organisational Development Journal, 17, 7, 33-35. http://dx.doi.org/10.1108/01437739610148367

Spears, L. C. (1998). Introduction: Tracing the Growing Impact of Servant-Leaders. L. C. Spears, ed. Insights on Leadership: Service, Stewardship, Spirit, and Servant-Leadership, New York, NY: John Wiley 1-12.

Starratt, R. (2004). Ethical leadership. San Francisco: Jossey-Bass Publishers, 62-109.

Thompson, R. S. (2002). The perception of servant leadership characteristics and job satisfaction in a church-related college. Unpublished dissertation, Indiana State University, Terre Haute, IN.

Waterman, H. (2011). Principles of servant leadership and how they can enhance practice. Nursing management, Volume 17, Number 9.

Whetstone, J. T. (2002). Personalism and moral leadership: the servant leader with a transforming vision. Business Ethics: A European Review, 11(4), 385-392. http://dx.doi.org/10.1111/1467-8608.00298

Wong, P. T. P. \& Page, D. (2003). Servant leadership: An opponent-process model and the revised servant leadership profile. Servant Leadership Research Roundtable Proceedings. Retrieved November 26, 2010. [Online] Available: http://www.regent.edu/acad/global/publications/sl_proceedings/home.shtml

Table 1. The Contrast between Command-Leadership and Servant-Leadership

\begin{tabular}{|l|l|}
\hline Command-Leadership & Servant-Leadership \\
\hline A leader's objective is to be served. & A leader's objective is to serve others. \\
\hline $\begin{array}{l}\text { Interested primarily in the leader's image and } \\
\text { advancement. Self-preservation and personal image } \\
\text { is at the forefront of most decisions. }\end{array}$ & $\begin{array}{l}\text { Seeks to enable subordinates to advance to their fullest potential } \\
\text { by downplaying self and exalting others. The team or enterprise } \\
\text { and all its members are considered and promoted before self. }\end{array}$ \\
\hline $\begin{array}{l}\text { Entitlement of the position is more important than } \\
\text { its responsibilities. }\end{array}$ & $\begin{array}{l}\text { Responsibilities are more important than perks of positional } \\
\text { entitlement }\end{array}$ \\
\hline $\begin{array}{l}\text { Co-workers are seen and treated as inferiors } \\
\text { and not usually invited to participate in }\end{array}$ & $\begin{array}{l}\text { Co-workers are treated with respect as part of a team } \\
\text { who work together to accomplish a task and make }\end{array}$ \\
\hline Decision-making or offered important information. & Decisions with shared information. \\
\hline Easily accessible to only closest lieutenants. & $\begin{array}{l}\text { Often seen interacting with others and maintains an open door } \\
\text { atmosphere. }\end{array}$ \\
\hline
\end{tabular}

Table 2. Results of factor analysis

\begin{tabular}{|c|c|c|c|c|c|c|}
\hline \multirow[b]{2}{*}{ Measurement items } & \multicolumn{6}{|c|}{ Constructs } \\
\hline & $\begin{array}{l}\text { Altruis } \\
\mathrm{m}\end{array}$ & $\begin{array}{l}\text { Egalitar } \\
\text { ianism }\end{array}$ & $\begin{array}{c}\text { Emotion } \\
\text { al } \\
\text { Dimensi } \\
\text { on }\end{array}$ & $\begin{array}{l}\text { Manageri } \\
\text { al Skills }\end{array}$ & $\begin{array}{l}\text { Human } \\
\text { Skills }\end{array}$ & $\begin{array}{c}\text { Commitm } \\
\text { ent to } \\
\text { Communi } \\
\text { ty }\end{array}$ \\
\hline Helping subordinates succeed & *0.816 & & & & & \\
\hline Putting subordinates first & 0.762 & & & & & \\
\hline Serve with no expectation of reward & 0.748 & & & & & \\
\hline Commitment to growth of others & 0.717 & & & & & \\
\hline Empowering subordinates & 0.673 & & & & & \\
\hline Sacrifice personal benefits & 0.658 & & & & & \\
\hline $\begin{array}{l}\text { Forming fair relationships with } \\
\text { subordinates }\end{array}$ & & 0.824 & & & & \\
\hline Valuing diversity and difference & & 0.802 & & & & \\
\hline
\end{tabular}




\begin{tabular}{|c|c|c|c|c|c|c|}
\hline \multirow[b]{2}{*}{ Measurement items } & \multicolumn{6}{|c|}{ Constructs } \\
\hline & $\begin{array}{l}\text { Altruis } \\
\mathrm{m}\end{array}$ & $\begin{array}{l}\text { Egalitar } \\
\text { ianism }\end{array}$ & $\begin{array}{c}\text { Emotion } \\
\text { al } \\
\text { Dimensi } \\
\text { on }\end{array}$ & $\begin{array}{l}\text { Manageri } \\
\text { al Skills }\end{array}$ & $\begin{array}{c}\text { Human } \\
\text { Skills }\end{array}$ & $\begin{array}{l}\text { Commitm } \\
\text { ent to } \\
\text { Communi } \\
\text { ty }\end{array}$ \\
\hline Encourage debate & & 0.786 & & & & \\
\hline Encourage constructive criticism & & 0.763 & & & & \\
\hline Behave subordinates ethically & & 0.737 & & & & \\
\hline Behave subordinates ethically & & 0.714 & & & & \\
\hline Listening carefully to others & & & 0.842 & & & \\
\hline Empathy & & & 0.825 & & & \\
\hline Emotional healing & & & 0.798 & & & \\
\hline Recognize low morale & & & 0.784 & & & \\
\hline $\begin{array}{l}\text { Sensitivity to employees' personal } \\
\text { obligations outside the workplace }\end{array}$ & & & 0.771 & & & \\
\hline Foresight & & & & 0.872 & & \\
\hline Conceptual skills & & & & 0.857 & & \\
\hline Stewardship & & & & 0.849 & & \\
\hline Bias towards action & & & & 0.834 & & \\
\hline Purpose and vision & & & & 0.807 & & \\
\hline Comfortable with technology & & & & 0.786 & & \\
\hline Awareness & & & & & 0.818 & \\
\hline Persuasion & & & & & 0.811 & \\
\hline Creating trust & & & & & 0.802 & \\
\hline Valuing people & & & & & 0.787 & \\
\hline $\begin{array}{l}\text { Treat people as ends rather than } \\
\text { means }\end{array}$ & & & & & 0.745 & \\
\hline $\begin{array}{l}\text { Engages in community service and } \\
\text { volunteer activities outside of work }\end{array}$ & & & & & & 0.837 \\
\hline Concern for helping the community & & & & & & 0.826 \\
\hline $\begin{array}{l}\text { Concern for effects of decisions on } \\
\text { community }\end{array}$ & & & & & & 0.814 \\
\hline $\begin{array}{l}\text { Creating value for those outside the } \\
\text { organization }\end{array}$ & & & & & & 0.794 \\
\hline Make federations of corporations & & & & & & 0.776 \\
\hline
\end{tabular}

* The loading factor 

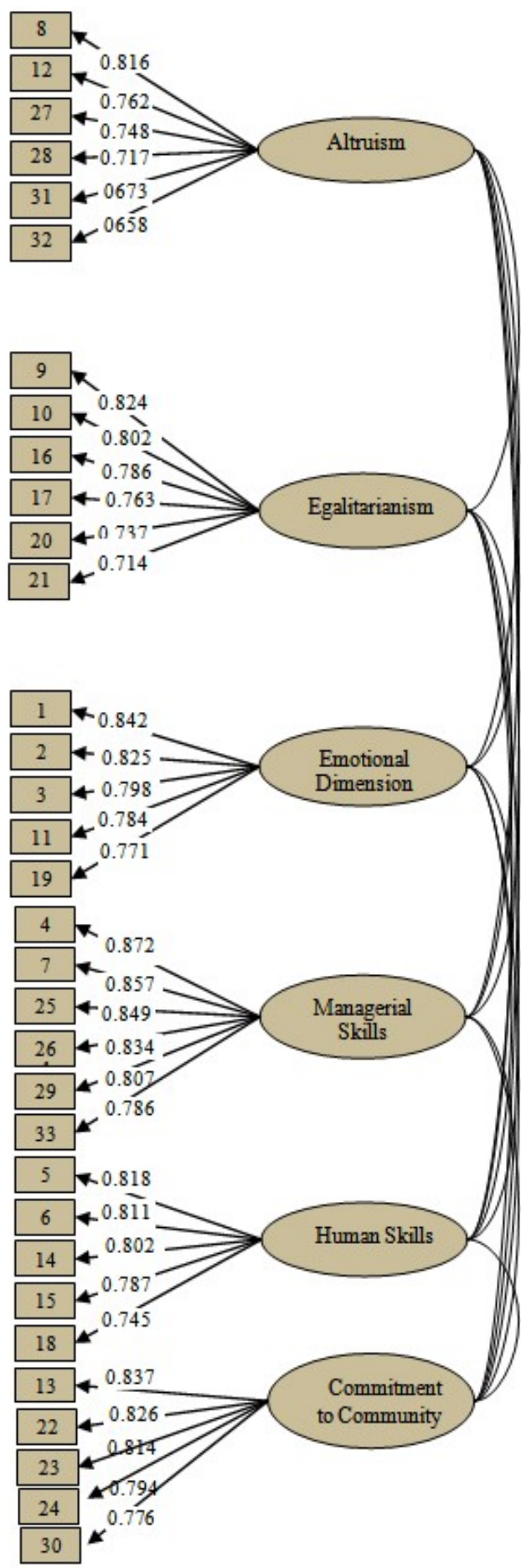

Figure 1 - The six factor SL model

(The columns from left to right indicate the item numbers and loading factors) 